\section{MARIOLA JAWORSKA}

Uniwersytet Warmińsko-Mazurski w Olsztynie, Polska https://orcid.org/0000-0002-7581-4194
Copyright and License: Copyright by Instytut Języka Polskiego PAN, Kraków 2021. This article is published under the terms of the Creative Commons Attribution - NoDerivatives 4.0 International (CC BY- ND 4.0) License (https:// creativecommons.org/licenses/by-nd/4.0/legalcode.pl).

\title{
JĘZYK SPECJALISTYCZNY DLA POTRZEB BIZNESOWYCH W PERSPEKTYWIE GLOTTODYDAKTYCZNEJ - PROJEKT BADAŃ
}

Słowa kluczowe: język specjalistyczny, język biznesu, kształcenie językowe dla potrzeb biznesowych, glottodydaktyka specjalistyczna, projekt badania.

\section{STRESZCZENIE}

Tematem artykułu jest nauczanie języka specjalistycznego dla potrzeb biznesowych, analizowane w perspektywie glottodydaktycznej. Rosnące potrzeby związane z wykorzystywaniem języków obcych w pracy zawodowej, także - w szeroko rozumianym biznesie, sprawiają, że jest to zagadnienie ważne zarówno w perspektywie dyskursu naukowego, jak i w kontekście poszukiwania nowych rozwiązań programowych. Specyfika podejmowanych działań komunikacyjnych, obejmująca nie tylko umiejętność porozumiewania się w danym języku obcym, lecz także wiedzę specjalistyczną, znajomość terminologii czy kulturowych uwarunkowań procesu komunikacji oraz zwiększające się potrzeby i oczekiwania dydaktyczne implikują konieczność prowadzenia dogłębnych analiz naukowych w zakresie kształcenia językowego dla potrzeb biznesowych. Opracowanie zawiera projekt badania odnoszącego się do wybranych aspektów kształcenia językowego na etapie szkoły wyższej ze szczególnym uwzględnieniem nauczania niemieckiego języka biznesu (jako obcego). Przedstawiono znaczenie problemu oraz dotychczasowy stan wiedzy na temat kształcenia w zakresie języka specjalistycznego dla potrzeb biznesowych, a także założenia projektu, cele, problemy badawcze i metodologię. Główne pytanie badawcze dotyczy specyfiki procesu uczenia się i nauczania języka biznesu na etapie szkoły wyższej i możliwości wpływania na niego w celu jego optymalizacji. Zaprojektowane badania mają pozwolić lepiej zrozumieć rolę zmiennych indywidualnych w procesie uczenia się i nauczania języka specjalistycznego dla potrzeb biznesowych, uchwycić specyfikę strategii uczenia się w tym zakresie, jak również oszacować możliwości wykorzystywania nowych technologii oraz tekstów multimodalnych w kształceniu w zakresie języka specjalistycznego.

\section{WPROWADZENIE}

Rosnąca popularność socjalnych odmian języka, w tym - języków specjalistycznych, oraz ich znacząca rola w komunikacji między przedstawicielami różnych narodów i kultur pociągają za sobą konieczność systematycznego ich badania. Obszarem ciągle dość rzadko analizowanym w tym kontekście w ramach studiów językoznawczych jest biznes, czyli działalność realizowana w warunkach gospodarki wolnorynkowej, 
z inicjatywy samodzielnych podmiotów, gospodarujących prywatnym kapitałem, która jest ukierunkowana na osiągnięcie zysku i podejmowana pomimo ryzyka (Pomykało 1995, 77-78). Językoznawcy zajmujący się dotychczas tym zagadnieniem koncentrują się na współczesnej postaci języka biznesu i zwykle go zawężają do wybranej odmiany, np. business communication (Ćwiklińska i Szadyko 2005) czy języka mówionego (Kochan $2010)^{1}$. Nieliczne okazują się próby kompleksowego przeanalizowania tego zagadnienia, odnoszące się do osiągnięć współczesnych badań naukowych (przede wszystkim lingwistyki języków specjalistycznych), a te dotychczas podejmowane uwzględniają najczęściej perspektywę translatoryczną (np. Ćwiklińska 2006) lub glottodydaktyczną, przy czym w tym ostatnim zakresie - przede wszystkim polonistyczną (Cudak i Tambor 1996; Łyda 1997; Mamet 2002; Wilk-Janik 2000; Ligara i Szupelak 2012).

Zwiększające się potrzeby związane z wykorzystywaniem języków obcych w pracy zawodowej, także w szeroko rozumianym biznesie, sprawiają, że ważnym zagadnieniem również w perspektywie akademickiej - staje się kształcenie językowe w tym zakresie. Kluczową rolę odgrywa tutaj nie tylko umiejętność porozumiewania się w danym języku obcym, lecz także wiedza specjalistyczna, znajomość terminologii czy kulturowych uwarunkowań procesu komunikacji, niezbędnych do tego, żeby mógł on przebiegać w sposób niezakłócony i efektywny. Specyfika podejmowanych działań komunikacyjnych oraz zwiększające się potrzeby i oczekiwania dydaktyczne implikują konieczność prowadzenia dogłębnych analiz naukowych w zakresie kształcenia językowego dla potrzeb biznesowych, ale także opracowywania nowych rozwiązań programowych.

Powyższe spostrzeżenia stały się przyczynkiem do zaprojektowania badania odnoszącego się do wybranych aspektów kształcenia w zakresie języka specjalistycznego na etapie szkoły wyższej ze szczególnym uwzględnieniem nauczania niemieckiego języka biznesu (jako obcego). W dalszej części artykułu zostaną przedstawione pytania badawcze, cele i koncepcja badań, a także metodologia, z wykorzystaniem której przebiegnie weryfikacja określonych zagadnień. Z uwagi na ograniczone rozmiary artykułu, podyktowane wymaganiami formalnymi czasopisma, niektóre zagadnienia nakreślono skrótowo.

\section{ZNACZENIE PROBLEMU ORAZ DOTYCHCZASOWY STAN WIEDZY}

\subsection{Język specjalistyczny dla potrzeb biznesowych}

Język biznesu, jak każdy język specjalistyczny, wzbogaca się i będzie się wzbogacał. Nie stanowi jedynie terminologicznego dodatku do języka ogólnego, ale różni się od niego specyficznymi cechami na wszystkich poziomach językowych. Nie ma charakteru uniwersalnego, może zatem wykazywać znaczne różnice w odmiennych językach

\footnotetext{
${ }^{1}$ Istotny przyczynek do badań nad specyfiką i kształtowaniem się polskiego języka biznesu stanowi rozprawa Pauliny Gajdy-Gałuszki (2018) Ksztaltowanie się polskiej terminologii biznesowej (na przykladzie „Czasu” z lat 1870-1914). Analiza semantyczna.
} 
(Spillner 1983) - co staje się istotną przesłanką dla organizacji kształcenia językowego w tym zakresie.

W polskojęzycznej literaturze lingwistycznej występuje wiele terminów odnoszących się do języka używanego w obrębie jakiejś dyscypliny, charakterystycznego dla komunikowania się określonej grupy specjalistów. Są to - przykładowo - pojęcie najczęściej używane, czyli język specjalistyczny, a także subjęzyk, język profesjonalny, język fachowy, język zawodowy, profesjolekt czy technolekt. Mnogość określeń występuje także na gruncie niemieckim, gdzie również funkcjonuje szereg pojęć odnoszących się do omawianego zjawiska, np. Fachlekt, Berufssprache, Arbeitssprache, Fachjargon, Expertensprache, Spezialsprache, Technolekt (S. Grucza 2013), a terminem dominującym w literaturze naukowej jest Fachsprache. Wszystkie wymienione wyrazy wskazują na istnienie niezależnej formy języka, będącej częścią naturalnego systemu językowego, która w inny sposób niż język ogólny wykorzystuje elementy morfologiczne, syntaktyczne i leksykalne. To wszystko powoduje, że specyficzne dla języka specjalistycznego są nie tylko odrębna terminologia, lecz także pewne autonomiczne cechy strukturalne (Całus 1985).

Sambor Grucza (2013) zauważa, że pojęcie język specjalistyczny okazuje się wieloznaczne i tradycyjnie to, do czego się odnosi, jest traktowane jako rodzaj wariantów czy odmian języka ogólnego. Tymczasem analizy dotyczące języków specjalistycznych trzeba rozpocząć od pytania o rzeczywiste języki specjalistyczne, czyli od tego, co istnieje rzeczywiście, a nie - od pytania o pewne uogólnienia nazywane językiem specjalistycznym. Prymarna funkcja języków specjalistycznych nie ogranicza się wszakże do komunikacyjnej, lecz jest podrzędna w stosunku do kognitywnej, przejawiającej się w wytwarzaniu, porządkowaniu i utrwalaniu wiedzy specjalistycznej w obrębie ludzkich mózgów. Lingwistyka języków specjalistycznych nie może zatem zawężać się do analizowania ich wyłącznie jako „narzędzi”, lecz powinna badać je w szerszym kontekście, pewnych „właściwości” konkretnych specjalistów. Podstawowym materiałem badawczym, od którego można rozpoczynać rekonstrukcje języków specjalistycznych, są zatem teksty specjalistyczne.

Istotny okres dla rozwoju polskich języków specjalistycznych, w tym - polskiego języka biznesu, rozpoczął się po 1870 roku, gdy kształtowało się polskie środowisko naukowo-techniczne, którego ,zasługą jest umiejętne wypracowanie wielu języków specjalistycznych i uczynienie z nich narzędzia porozumiewania się szerokiego kręgu użytkowników" (S. Gajda 1997, 14-15). Pierwszą polską monografią dotyczącą języków specjalistycznych, napisaną z perspektywy lingwistyki, było Wprowadzenie do teorii terminu Stanisława Gajdy (1990), stanowiące moment przełomowy w polskich rozważaniach z zakresu terminologii czystej. Kolejną rozprawą dostarczającą istotnych podstaw teoretycznych dla analizowanego zagadnienia jest Lingwistyka języków specjalistycznych Sambora Gruczy (2013). Autor, nawiązujący do osiągnięć Franciszka Gruczy (1994), podkreśla $\mathrm{w}$ niej rolę języków specjalistycznych polegającą na pełnieniu funkcji komunikacyjnych nie tylko w obrębie określonej grupy zawodowej, lecz także w rozwoju ludzkiej cywilizacji w ogóle. Tak rozumiana lingwistyka języków specjalistycznych nie 
może ograniczać analiz wyłącznie do terminologii poszczególnych języków, ale musi włączyć w zakres swych zainteresowań również teksty oraz dyskursy specjalistyczne, którym - zdaniem Gruczy - we współczesnych badaniach lingwistycznych poświęca się zbyt mało uwagi, wskutek ograniczania się do tworzenia leksykonów określonych języków specjalistycznych.

$\mathrm{Na}$ gruncie polskim powstało niewiele prac naukowych, których tematem stałby się - bezpośrednio - język specjalistyczny dla potrzeb biznesowych. Nieliczne, które zostały dotąd opublikowane, odnoszą się zazwyczaj do kształcenia cudzoziemców w Polsce, np. Polski język biznesu dla cudzoziemców autorstwa Anny Butcher i Anny Dunin-Dudkowskiej (1998). Rozważania dotyczące polskiego języka biznesu, czym w istocie jest i co go charakteryzuje, przedstawili także Romuald Cudak i Jolanta Tambor w artykule „Czy istnieje polski język biznesu?” (1996). Wskazali na charakterystyczne tendencje zauważalne w analizowanym obszarze, takie jak: bezwzględna przewaga zapożyczeń właściwych nad wszelkimi innymi sposobami wzbogacania terminologii (neosemantyzacja, zapożyczenia na prawach cytatu, zapożyczanie połączone z wprowadzeniem zapożyczeń w polski system fleksyjny i/lub słowotwórczy, spolszczanie pisowni zapożyczeń); przymiotnikowe jednowyrazowe przydawki w miejsce dopełniaczowych i przyimkowych; nominalizowanie. W podsumowaniu autorzy stwierdzili, że polski język biznesu to leksyka specjalna wraz ze składniowo-fleksyjnymi uwarunkowaniami jej użycia.

Rozważania na temat cech i funkcji języka biznesu w początkowej fazie kształtowania prowadziła Paulina Gajda w artykule „Cechy polskiego języka biznesu jako języka specjalistycznego w początkowym etapie kształtowania się [...]" (2015). W odniesieniu do prac Franciszka Gruczy (1994) autorka podkreśliła, że język biznesu, jako język specjalistyczny, nigdy nie był wyłącznie narzędziem służącym porozumiewaniu się, ponieważ jego nadrzędną rolą stało się umożliwienie rozwoju kognitywnego oraz praktycznego użytkownikom. Ta funkcja jest realizowana przede wszystkim w obszarze leksykalno-semantycznym języka biznesu, co wiąże się z tym, że jego morfologia czy syntaktyka zasadniczo pokrywają się z analogicznymi warstwami języka ogólnego (niektóre ze struktur występują częściej), z kolei leksyka okazuje się w dużym stopniu odrębna. Każda z funkcjonalnych odmian języka biznesu jest reprezentacją mentalną innego wycinka rzeczywistości. W każdej (języku handlu, giełdy, produkcji itp.) znajdziemy także „terminy będące znakami pojęć pewnych obiektów (np. w języku giełdy: obligacje pierwszeństwa, listy zastawne, konsole, ceduła giełdowa), instytucji (np. w języku handlu: centrum handlowe, giełda towarowa, giełda zbożowa, targowica) czy czynności (np. w języku giełdy: eskontować (weksle), emitować (papiery wartościowe), konwertować (listy zastawne) typowych tylko dla tej dziedziny, którą ów język obsługiwał" (P. Gajda 2015, 50).

Próby poszerzenia perspektywy studiów nad językami specjalistycznymi, przede wszystkim o aspekty związane z płaszczyzną tekstową, podjęto także w krajach niemieckojęzycznych. Historię powstawania niemieckich języków przedstawili Lubomir Drozd i Wilfried Seibicke w książce Deutsche Fach- und Wissenschaftssprache. 
Bestandsaufnahme - Theorie - Geschichte (1973). Problem pogłębili i poszerzyli Jörn Albrecht i Richard Baum w publikacji Fachsprache und Terminologie in Geschichte und Gegenwart z 1982 roku. Najpełniejsze dotąd opracowania różnych perspektyw i koncepcji badań nad językami specjalistycznymi odnajdziemy natomiast w pracy zbiorowej Fachsprachen. Ein internationales Handbuch zur Fachsprachenforschung und Terminologiewissenschaft, która ukazała się w 1998 roku pod redakcją naukową Lothara Hoffmanna, Hartwiga Kalverkämpera i Herberta Wieganda, a także w monografii Thorstena Roelcke Fachsprachen (2001). Charakterystyczne dla germanistycznej lingwistyki języków specjalistycznych jest poszukiwanie odpowiedzi na pytanie, co różni języki specjalistyczne od języka ogólnego.

Na odrębność niemieckiego języka biznesu jako języka specjalistycznego w podsystemie leksykalnym i syntaktycznym wskazują takie jego cechy, jak (Całus 1985): 1. dokładność i terminologiczność - charakterystyczna jest duża liczba rzeczowników stanowiących precyzyjne, fachowe terminy i wyrażenia (np. der Schuldschein - 'skrypt dłużny', die Wertpapierbörse - 'giełda papierów wartościowych'); 2. jednoznaczność nazewnictwa i jednomianowość (np. die Charta - 'statut spółki', die Aktie - 'akcja, papier wartościowy'); 3 . systematyczność, wyrażana poprzez logiczną hierarchię pojęć, definicji oraz strukturę budowy tekstów (np. der Aktionär - 'udziałowiec', die Hauptversammlung - 'zebranie udziałowców'), charakterystyczne jest nasycenie tekstów słowami obcymi, zapożyczeniami, internacjonalizmami (np. das Meeting - zebranie, der Workshop - warsztaty); 4. operatywność, która przejawia się w posługiwaniu się międzynarodowymi symbolami, wykorzystywaniu metod słowotwórczych, skrótów (np. DDP, czyli delivered duty paid - 'dostarczone, cło opłacone', CIF, czyli cost, insurence, freight - 'koszt, ubezpieczenie'). Syntaktyczna struktura daje językowi specjalistycznemu wiele możliwości budowy określonych modeli zdań i zwrotów.

W kontekście tekstów specjalistycznych należy podkreślić rolę, jaką może w nich odgrywać multimodalność, rozumiana jako współistnienie i współgranie - na jednej płaszczyźnie wizualnej (Schmitz 2001) czy też w jednym tekście językowo-obrazowym (Stöckl 2004) - reprezentantów różnych systemów semiotycznych. Na współczesny dyskurs w dużej mierze składają się przekazy multimodalne, w których słowo i obraz wzajemnie się kontekstualizują, w wyniku czego tworzą spójne jednostki znaczeniowe. W tekstach ekonomiczno-biznesowych te połączenia występują szczególnie często, z uwagi na konieczność wizualizacji wielu informacji. Język specjalistyczny dla potrzeb biznesowych urzeczywistnia się zatem zarówno na płaszczyźnie werbalnej, jak i na wizualnej, przy czym obraz wypełnia często luki semantyczne pojawiające się na płaszczyźnie językowej tekstu. Nadawca i odbiorca komunikatu muszą zatem mieć tzw. kompetencję multimodalną, dzięki której możliwe staje się angażowanie elementów językowych i obrazowych do budowania spójnego przekazu. Niezwykle ważne wydaje się dostrzeżenie roli i przydatności multimodalności w procesie uczenia się i nauczania języka specjalistycznego, gdyż pozwala ona wdrożyć uczących się do sprawnie realizowanej i skutecznej komunikacji, która współcześnie przyjmuje właśnie taką, tj. multimodalną, postać (Makowska 2018). 


\subsection{Kształcenie w zakresie języka specjalistycznego dla potrzeb biznesowych}

Początki dydaktyki języków specjalistycznych przypadają na tzw. okres leksykalny i syntaktyczny w badaniach nad językami specjalistycznymi, obejmujący lata 1950-1970, w którym kształcenie w zakresie języka specjalistycznego utożsamiano przede wszystkim z poznawaniem i opracowywaniem terminologii i specyficznych struktur składniowych (S. Grucza 2002, 80-81). W kolejnych latach jako cele dydaktyki języków specjalistycznych wskazywano dążenie do opanowania podstawowej terminologii, najważniejszych struktur językowych w zakresie języka specjalistycznego oraz rozwijanie kompetencji przetwarzania i rozumienia tekstu specjalistycznego w ścisłym powiązaniu z kompetencją leksykalną. W latach 90 . XX wieku perspektywę badawczą poszerzono o zagadnienia związane z komunikacją specjalistyczną. Aby komunikować się w grupie specjalistów, potrzebna okazuje się - oprócz językowej - kompetencja (inter)kulturowa, pragmatyczna, dyskursywna (Mamet 2002), a ponadto także kompetencja zawodowa, czyli dysponowanie pewnym zakresem wiedzy i umiejętności fachowych w danej dziedzinie, bez których wiedza językowa byłaby niewystarczająca, aby móc efektywnie uczestniczyć w komunikacji.

Kształcenie językowe dla potrzeb zawodowych stało się w ostatnich latach jednym z ważniejszych zagadnień realizowanych w ramach badań glottodydaktycznych - czego dowodem są liczne publikacje $\mathrm{w}$ tym zakresie. Wiele artykułów poświęconych omawianej problematyce ukazało się w czasopismach, takich jak Przeglad Glottodydaktyczny, Lingwistyka Stosowana czy Neofilolog, którego dwa numery, 41/1 i 42/2, zostały poświęcone wyłącznie tej tematyce (Nauczanie/uczenie się języków specjalistycznych). Bardziej kompleksowe ujęcie, niż jest to możliwe w ramach publikacji artykułów w czasopismach, odnajdziemy w monografii Elżbiety Gajewskiej i Magdaleny Sowy LSP, FOS, Fachsprache... Dydaktyka języków specjalistycznych (2014), która systematyzuje wiedzę w zakresie problematyki języków obcych dla celów specjalistycznych, z uwzględnieniem zarówno perspektywy lingwistycznej, jak i glottodydaktycznej (czystej i stosowanej). Prowadzone analizy, obejmujące główne języki obce w polskim systemie edukacyjnym, odnoszą się do różnorodnych aspektów procesu uczenia się i nauczania języków obcych do celów zawodowych: zestawiają teorie i koncepcje różnych autorów i zmierzają do pokazania szerokiego zakresu problemów poruszanych w ramach glottodydaktyki specjalistycznej.

Nauczanie języków specjalistycznych - ojczystego i obcego - kontrastywnie ujęli Bronisława Ligara i Wojciech Szupelak w publikacji Lingwistyka i glottodydaktyka języków specjalistycznych na przykładzie języka biznesu. Podejście porównawcze (2012). Autorzy przeprowadzili porównanie kształcenia w zakresie polskiego języka biznesu z nauczaniem analogicznej odmiany języka angielskiego, a przy tym obrali perspektywę nauczania polskiego języka specjalistycznego jako obcego. W monografii omówiono podstawy teoretyczne nauczania języka specjalistycznego jako obcego oraz kwestię nauczania polskiego języka biznesu jako obcego w perspektywie porównawczej obejmującej nauczanie języka angielskiego. 
Perspektywę glottodydaktyczną związaną z językiem biznesu przyjęła także Jolanta Wilk-Janik, która w artykule „Język biznesu: jego cechy i implikacje dla glottodydaktyki” (2000) analizowała m.in. kwestię strategii i technik stosowanych do przyswajania języka biznesu jako języka drugiego/obcego. W wyniku przeprowadzonego badania stwierdziła, że występuje znaczne podobieństwo w ilościowym i jakościowym stosowaniu technik uczenia się zarówno języka obcego w odmianie ogólnej, jak i języka obcego dla celów zawodowych. Z kolei wybór strategii uczenia się potwierdza, że uczący się - częściej niż w przypadku uczenia się języka ogólnego - stosują strategie kognitywne, z wykorzystaniem posiadanej wiedzy.

W przeglądzie literatury dotyczącej perspektywy glottodydaktycznej należy odnotować, że w 2020 roku powstała rozprawa doktorska Ewy Komorowskiej zatytułowana Nauczanie języka polskiego jako obcego dla potrzeb biznesowych na najniższych poziomach zaawansowania językowego, przygotowana pod kierunkiem prof. dr. hab. Władysława T. Miodunki. Nie została ona jednak dotąd udostępniona szerokiemu gronu odbiorców.

W rozważaniach dotyczących specjalistycznego kształcenia językowego pojawiają się także tematy związane z zagadnieniem multimodalności. Potencjał tekstów multimodalnych w kontekście ich wykorzystywania w procesie kształcenia językowego, a tym samym - optymalizacji nauczania języka obcego, dostrzegają np. Anna Basińska (2017) czy Richard Mayer (2013). Tematy związane z mediami audiowizualnymi podejmują chętnie zwłaszcza naukowcy niemieckojęzyczni (m.in. Abraham 2006, 2009, 2013; Schmäling 2014; Spaniel-Weise 2014; Chmielewska-Molik 2019). Jednak badania i analizy w tym zakresie prowadzone nie odnoszą się do języka biznesu.

\section{PROJEKT BADANIA}

\subsection{Założenia, cele i problemy badawcze}

Wyniki przywołanych badań dotyczących kształcenia w zakresie języka specjalistycznego, własne obserwacje oraz wnioski z nich płynące, a także - zauważalne potrzeby związane z ofertą programową, stały się bodźcem do zaprojektowania badań glottodydaktycznych mających stanowić przyczynek do opracowania podstaw instytucjonalnego nauczania języków specjalistycznych dla potrzeb biznesowych (na przykładzie języka niemieckiego). Ich głównym celem stało się uporządkowanie wiedzy w zakresie omawianego zagadnienia, a także rozwinięcie ustaleń teoretycznych. W wymiarze praktycznym wyniki analiz mogą przyczynić się do optymalizacji procesu uczenia się i nauczania niemieckiego języka biznesu, przede wszystkim jako pomoc w konstruowaniu nowych programów kształcenia oraz materiałów dydaktycznych możliwych do wykorzystania w kształceniu na studiach wyższych. Na szczególną uwagę zasługuje w tym obszarze wykorzystywanie intensywnie rozwijających się technologii informacyjno-komunikacyjnych².

\footnotetext{
${ }^{2}$ Projekt nie obejmuje zagadnień związanych z doborem nauczanej treści specjalistycznej. Ponieważ obszar specjalistyczny biznesu jest tak różnorodny i obejmuje tak liczne subdomeny specjalistyczne,
} 
Po przyjęciu założenia, w myśl którego jednym z głównych zadań glottodydaktyki specjalistycznej jest analiza uwarunkowań przyswajania i nauczania wiedzy specjalistycznej z myślą o optymalizacji procesu uczenia się i nauczania (Fluck 1992, 5-6), główne pytanie badawcze sformułowano następująco: Jak przebiegają procesy uczenia się niemieckiego języka biznesu na etapie szkoły wyższej i w jaki sposób można na nie wpływać, aby je optymalizować? W związku z tak ujętym celem nadrzędnym postawiono następujące pytania szczegółowe: 1) Jaką rolę odgrywają wybrane różnice indywidualne w uczeniu się języka dla potrzeb biznesowych, a także jakie są relacje między nimi? 2) Jakie techniki i strategie uczenia się stosują badani w przyswajaniu niemieckiego języka biznesu? Czy - a jeśli tak, to w jakim zakresie - są one podobne do tych, z którymi mamy do czynienia w przypadku języka ogólnego? 3) W jaki sposób wykorzystywanie technologii informacyjno-komunikacyjnych wpływa na przyswajanie języka biznesu? 4) Jaką rolę w procesie kształcenia językowego dla potrzeb biznesowych odgrywa wykorzystanie tekstów multimodalnych?

Poprawna analiza zjawisk komunikacyjnych, zwłaszcza w komunikacji zawodowej, wymaga uwzględnienia kontekstu, w jakim one występują, czyli elementów takich jak czas, miejsce, cele i skutki komunikacji, jej kanał, treść i forma, uczestnicy (Hymes 1964 za: Gajewska i Sowa 2014, 28). W przygotowaniu do porozumiewania się w języku obcym w kontekście specjalistycznym szczególnego znaczenia nabiera ostatni z wymienionych elementów, czyli uczestnicy komunikacji i ich cechy indywidualne. Dlatego jednym z zagadnień zaplanowanych w ramach badań jest analiza znaczenia wybranych różnic indywidualnych w procesie uczenia się i nauczania niemieckiego języka biznesu. Zmienne indywidualne, omawiane w literaturze także jako cechy indywidualne, to różnice przejawiające się w zmienności cech (Matczak 1992, 83), powodujące, że jednostki należące do tej samej populacji różnią się pod względem porównywanych zachowań oraz charakterystyk fizycznych i psychicznych. Interesujący okazuje się sposób, w jaki czynniki indywidualne, takie jak sklonność do podejmowania ryzyka, tolerancja wieloznaczności, empatia, zależność/niezależność od pola czy lęk komunikacyjny, modelują komunikację specjalistyczną. Badania empiryczne pozwalające lepiej poznać specyfikę i funkcjonowanie różnic indywidualnych mogą być przydatne do uzyskania pełniejszego obrazu określonych czynników, z uwzględnieniem ich wielowymiarowego charakteru, dynamiki i osadzenia w konkretnym kontekście komunikacji specjalistycznej. Za podstawę analiz w tym zakresie posłuży paradygmat kognitywno-afektywny. Właśnie z najnowszych badań poświęconych czynnikom afektywnym i poznawczym wynika, że przenikają się one podczas uczenia się języków (np. Wolff 2004; Neveling 2004; Griffiths 2008) i stają się tym elementem procesu uczenia się, który charakteryzuje dynamiczna interakcja (Biedroń 2019, 31). Przyjęcie takiej perspektywy analiz wydaje się w pełni uzasadnione, gdyż obydwa obszary, zarówno emocjonalny, jak i poznawczy, wspólnie kształtują ludzkie działanie, a co za tym idzie - również działanie językowe (Wolff 2004, 92).

przedmiotem badania stała się użyteczność podejść, strategii i technik nauczania z punktu widzenia uczących się. 
Celem glottodydaktyki specjalistycznej jest kształtowanie umiejętności działania językowego w określonej sferze zawodowej, w tym przypadku - w działalności biznesowej. Zatem w programowaniu zajęć można stosować takie podejścia, jak: zorientowanie na język (celem jest opanowanie terminologii i struktur gramatycznych), zorientowanie na rozwój sprawności (cel jest zależny od potrzeb uczących się) oraz zorientowanie na tekst (akcent położony na pracę z tekstem specjalistycznym). Szczególnie ciekawe poznawczo - także z perspektywy autonomizacji uczących się - są podejścia zorientowane na uczenie się, w których kładzie się akcent na uczącego się i na pokazywanie mu skutecznych technik i strategii autonomicznego uczenia się (Fluck 1992, 1996, 1998). Dlatego ważnym aspektem zaplanowanym do analizy w ramach projektowanych badań są strategie i techniki stosowane przez badanych w procesie uczenia się niemieckiego języka biznesu z uwzględnieniem podobieństw i różnic w stosunku do tych, z którymi mamy do czynienia w przypadku uczenia się języka ogólnego. Strategie uczenia się są zagadnieniem ostatnio dosyć dobrze zbadanym przez specjalistów, jednak niewiele danych ukazuje tę problematykę w kontekście języka specjalistycznego. Ustalenia w tym zakresie mogą dostarczyć wskazówek dotyczących sposobów optymalizacji procesu uczenia się i nauczania języka biznesu jako obcego.

Kolejne szczegółowe pytanie badawcze odnosi się do określenia uwarunkowań i perspektyw wykorzystania technologii informacyjno-komunikacyjnych w uczeniu się i nauczaniu niemieckiego języka biznesu. O szerokich możliwościach wykorzystania komputera w nauce języków obcych wiadomo od dawna: jego stosowanie może aktywizować uczącego się w osiąganiu takiego poziomu umiejętności językowych, komunikacyjnych i interkulturowych, który będzie zgodny - z jednej strony - z jego własnymi potrzebami, a z drugiej - z określonymi w programie nauczania celami edukacyjnymi. Hermann Funk (1999) określił aktualne do dziś główne obszary wykorzystania komputera w nauce języków obcych: są to m.in. trening, komunikacja, informacja i obróbka tekstu. Odnoszą się one do kształtowania wszystkich umiejętności językowych, ale także takich elementów, jak krajoznawstwo czy kulturoznawstwo.

Podstawę do osiągnięcia celu związanego z odpowiedzią na pytanie, w jakim stopniu media elektroniczne mogą być wykorzystywane w uczeniu się i nauczaniu języka specjalistycznego dla potrzeb biznesowych, będą stanowiły analizy obecnego stanu ich rozwoju w kontekście możliwości ich wykorzystania w kształceniu językowym dla potrzeb biznesowych. Ciekawą kwestią w tym kontekście okazuje się możliwość wykorzystania - zarówno w ramach zajęć audytoryjnych, jak i pozaaudytoryjnych oryginalnych materiałów edukacyjnych (np. internetowych banków danych, stron informacyjnych lub reklamowych, wzorów dokumentów, wirtualnych muzeów, stron biur podróży, forów podróżniczych). Szczególnie przydatne wydają się dokumentalne lub szkoleniowe materiały wideo przedstawiające interakcje ustne.

Celem odpowiedzi na ostatnie pytanie szczegółowe stanie się oszacowanie możliwości zastosowania poszczególnych rodzajów tekstów multimodalnych w procesie kształcenia językowego dla potrzeb biznesowych. Szczególny nacisk zostanie przy tym położony na rolę czynników afektywnych w odbiorze komunikatów, mających wpływ 
na chęć i gotowość do nauki niemieckiego języka biznesu. Analiza mediolingwistyczna wybranych tekstów multimodalnych zostanie przeprowadzona z uwzględnieniem zarówno kryteriów formalnych, jak i funkcjonalnych. Zajęcie się tym zagadnieniem wydaje się ważne, gdyż pomimo intensywnego rozwoju badań mediolingwistycznych, związanych z komunikacją multimodalną (Stöckl 2004; Perrin 2006; Schmitz 2001; Żebrowska 2013; Siever 2015) oraz z jej wpływem na różne dziedziny życia, powstało niewiele kompleksowych analiz, które skupiałyby się na znaczeniu multimodalności i wykorzystaniu jej potencjału w glottodydaktyce, tym bardziej w kontekście nauki języka specjalistycznego. Dostrzeżenie roli i przydatności multimodalności w procesie kształcenia językowego jest niezwykle istotne, gdyż przede wszystkim w ten sposób, tzn. multimodalnie, przebiega współcześnie komunikacja. Wnioski przyczynią się również do rozwoju nowej dziedziny naukowej, czyli dydaktyki logowizualnej (Schmitz 2001; Weidenmann 2009; Raith 2014).

\subsection{Ogólny plan i metodologia badań}

Zadania zaplanowane w ramach poszczególnych pytań szczegółowych będą realizowane równolegle przez trzyosobowy zespół badaczy w okresie następnych dwóch lat. Odpowiedzialność za poszczególne zagadnienia zostanie podzielona w taki sposób, aby $-\mathrm{z}$ jednej strony - zapewnić właściwe przyporządkowanie danych obszarów do doświadczenia i kompetencji poszczególnych badaczy, natomiast z drugiej - uwzględnić szeroką perspektywę głównego celu badawczego. Badania empiryczne zostaną przeprowadzone w roku akademickim 2021/2022, w ramach zajęć audytoryjnych, jak i pozaaudytoryjnych, z udziałem studentów Uniwersytetu Warmińsko-Mazurskiego w Olsztynie uczących się języka niemieckiego dla potrzeb biznesowych, którzy stanowić będą grupę badawczą (ok. 150 osób).

Projekt badawczy zaprezentowany w niniejszej publikacji zostanie zrealizowany z wykorzystaniem metodologii badań glottodydaktycznych (Wilczyńska i Michońska-Stadnik 2010). Dzięki jej zastosowaniu możliwe staje się zrozumienie procesów rozwijania kompetencji komunikacyjnej w zakresie języka specjalistycznego, przebiegających w różnorodnych kontekstach edukacyjnych i podlegających specyficznym uwarunkowaniom: zarówno indywidualnym, jak i zewnętrznym. Wiedza glottodydaktyczna w tym zakresie będzie budowana w toku konfrontacji rozważań teoretycznych i badań empirycznych. Teoretyczne ujęcia będą próbą uogólniania wybranych zjawisk i zależności, z kolei badania empiryczne okażą się próbą pogłębienia tego rozumienia poprzez odwzorowanie danego wycinka rzeczywistości z uwzględnieniem specyficznego kontekstu komunikacji specjalistycznej. Aspekty teoretyczny i empiryczny będą zatem się uzupełniać i wzajemnie odsyłać do siebie uzupełniać. W badaniach zostanie zastosowane podejście hybrydowe, uwzględniające zarówno jakościowy, jak i ilościowy sposób gromadzenia danych oraz strategię triangulacji. Metody i techniki badawcze obejmą: badanie w działaniu, studium przypadku, analizę dokumentów, ankietowanie zastosowanie kwestionariusza zawierającego zestawienie strategii (Jaworska 2018, 
238-241 na podstawie Oxford 1990), testowanie (Inwentarz Motywacji Osiągnięć, KNS - Kwestionariusz Nadziei na Sukces, Inwentarz Osobowości NEO-FFI').

Ponieważ w badaniach glottodydaktycznych niewiele prac odnosi się do postaw uczących się i do teorii subiektywnych związanych z wykorzystaniem tekstów multimodalnych w nauce języków obcych (Chmielewska-Molik 2019), analizy empiryczne zaplanowane w ramach realizacji tego celu zostaną oparte na metodologii jakościowej. Jej zastosowanie umożliwia „szczegółowy, możliwie wyczerpujący opis podmiotu/ przedmiotu badan - opis wieloperspektywiczny" (Jaroszewska 2020, 254), co wydaje się szczególnie istotne, gdy chce się analizować powyższy problem z perspektywy osób uczących się języków obcych. W ramach metodologii jakościowej badania są przeprowadzane w bezpośrednim kontakcie badacza $\mathrm{z}$ badanymi, a analiza staje się prowadzona z uwzględnieniem sytuacji osób badanych - pokazuje ich myśli, odczucia, opinie, motywy itp. (Jaworska 2018, 169). Takie podejście wydaje się zasadne, gdyż dla adekwatnego wyjaśniania zagadnień związanych z nauczaniem i uczeniem się języków obcych z zastosowaniem tekstów multimodalnych bardzo istotny jest opis cech indywidualnych i środowiska uczenia się badanych. W ramach metodologii jakościowej i z myślą o uzyskaniu możliwie szczegółowych danych zostaną zastosowane takie techniki i narzędzia, jak: swobodny wywiad z ogólnym planem zagadnień, niekontrolowana obserwacja uczestnicząca, jakościowa analiza dokumentów, studium przypadku, protokoły głośnego myślenia, testy umiejętności językowych.

\section{PODSUMOWANIE}

Celem niniejszego artykułu stało się nakreślenie ram teoretycznych i zasygnalizowanie intencji przeprowadzenia badania dotyczącego kształcenia językowego dla potrzeb biznesowych na przykładzie języka niemieckiego. Prowadzenie badań naukowych odnoszących się do tej kwestii może przyczynić się do rozwoju glottodydaktyki specjalistycznej, ale też mieć istotne implikacje dydaktyczne poprzez wpływ na opracowywanie metod, technik i materiałów dydaktycznych. Zaprojektowane badania mają pozwolić lepiej zrozumieć rolę zmiennych indywidualnych w procesie uczenia się i nauczania języka specjalistycznego dla potrzeb biznesowych. Określenie czynników indywidualnych uczącego się, jego indywidualnego profilu, może być warunkiem opracowania różnego rodzaju interwencji dydaktycznych, co z kolei wpływa na osiągane wyniki. Analiz w tym zakresie wymaga także użycie strategii uczenia się języków. Warto zbadać, jak wygląda ta kwestia w grupie osób uczących się języka specjalistycznego odnośnie do cech konkretnego języka, w tym przypadku - niemieckiego. Trzeba zauważyć, że istnieje wiele badań dotyczących strategii wykorzystywanych podczas nauki języków, jak i tych związanych z samym procesem przyswajania kolejnych języków. Jednak tematyka dotycząca porównania sposobu,

\footnotetext{
${ }^{3}$ Kwestionariusz do diagnozy cech osobowości uwzględnionych w popularnym modelu pięcioczynnikowym, określanym jako model Wielkiej Piątki.
} 
w jaki strategie uczenia się języka są wykorzystywane podczas nauki języka ogólnego i języka specjalistycznego, nie została dotąd zbadana i omówiona w wystarczającym stopniu. Ciekawy poznawczo okazuje się aspekt wykorzystywania nowych technologii w kształceniu w zakresie języka specjalistycznego, ponieważ diagnoza możliwości ich wykorzystania może wskazywać kierunki w metodologiczno-dydaktycznym i organizacyjnym kształtowaniu zajęć lekcyjnych. W tym kontekście istotna staje się także problematyka roli i przydatności multimodalności, przede wszystkim stosowania tekstów multimodalnych. Próba analizy wybranych tekstów z perspektywy multimodalności ma pokazać uwarunkowania i perspektywy ich wykorzystania w nauce zorientowanej na cele specjalistyczne.

\section{BIBLIOGRAFIA}

Abraham, U. 2006. „Mehr als nur «Theater mit Videos». Theatralität in einem medienintegrativen Deutschunterricht und szenische Verfahren im Umgang mit Film und Fernsehen”. W Filmdidaktik-Filmästhetik: Jahrbuch Medien im Deutschunterricht, red. V. Frederking. München: kopaed, 130-144.

Abraham, U. 2009. Filme im Deutschunterricht. Reihe Praxis Deutsch. Seelze: Klett.

Abraham, U. 2013. „Kurzspielfilme im Deutschunterricht”. Praxis Deutsch 237: 4-14.

Albrecht, J., i R. Baum. 1982. Fachsprache und Terminologie in Geschichte und Gegenwart. Tübingen: Narr.

Basińska, A. 2017. Teoria w pigułce, red. meryt. A. Gębka-Suska. Warszawa: ORE.

Biedroń, A. 2019. „Czynniki afektywne w teorii i badaniach nad zdolnościami językowymi”. Neofilo$\log 52$ (1): 29-41.

Butcher, A., i A. Dunin-Dudkowska. 1998. Polski język biznesu dla cudzoziemców. Lublin: Wydawnictwo Uniwersytetu Marii Curie-Skłodowskiej.

Całus, E. 1985. Wybrane aspekty nauczania języka specjalistycznego. Prace Naukowe SPNJO Politechniki Wrocławskiej 20. Wrocław: Wydawnictwo Politechniki Wrocławskiej.

Chmielewska-Molik, K. 2019. Fremdsprachenlernen mit Fernsehserien. Subjektive Lernertheorien (rozprawa doktorska). Poznań: UAM.

Cudak, R., i J. Tambor. 1996. „Czy istnieje polski język biznesu?”. Acta Universitatis Lodziensis. Ksztatcenie Polonistyczne Cudzoziemców 78: 109-120.

Ćwiklińska, J. 2006. „Źródła zakłóceń semantycznych w międzynarodowym komunikowaniu biznesowym”. Zeszyty Naukowe Kolegium Gospodarki Światowej 19: 137-147.

Ćwiklińska, J., i S. Szadyko. 2005. „Obszary wiedzy specjalistycznej w wybranych wariantach języka business communicaton”. W Języki specjalistyczne 5, red. J. Lewandowski, i M. Kornacka. Warszawa: Katedra Języków Specjalistycznych Uniwersytetu Warszawskiego, 81-88.

Drozd, L., i W. Seibicke. 1973. Deutsche Fach- und Wissenschaftssprache. Bestandsaufnahme - Theorie Geschichte. Wiesbaden: Brandstetter.

Fluck, H.R. 1992. Didaktik der Fachsprachen. Aufgaben und Arbeitsfelder, Konzepte und Perspektiven im Sprachbereich Deutsch. Tübingen: Narr.

Fluck, H.R. 1996. Fachsprachen: Einführung und Bibliographie. Tübingen - Basel: A. Francke Verlag. 
Fluck, H.R. 1998. „Fachsprachliche Ausbildung und Fachsprachendidaktik”. W Fachsprachen. Ein internationales Handbuch zur Fachsprachenforschung und Terminologiewissenschaft, red. L. Hoffmann, H. Kalverkämper, i H. Wiegand. Berlin - New York: de Gruyter, 944-954.

Funk, H. 1999. „Plädoyer für eine Scheibe”. Fremdsprache Deutsch 2: 45.

Gajda, S. 1990. Wprowadzenie do teorii terminu. Opole: Wyższa Szkoła Pedagogiczna im. Powstańców Śląskich w Opolu.

Gajda, S. 1997. „Polskie języki specjalistyczne dawniej i dziś”. W Języki specjalistyczne. Język biznesu, red. J. Arabski. Katowice: Wyższa Szkoła Zarządzania Marketingowego i Języków Obcych w Katowicach, 7-24.

Gajda, P. 2015. „Cechy polskiego języka biznesu jako języka specjalistycznego w początkowym etapie kształtowania się". INVESTIGATIONES LINGUISTICAE XXXIII: 43-54.

Gajda-Gałuszka, P. 2018. Ksztaltowanie się polskiej terminologii biznesowej (na przykladzie „Czasu” z lat 1870-1914). Analiza semantyczna. Kraków: Wydawnictwo Libron.

Gajewska, E., i M. Sowa. 2014. LSP, FOS, Fachsprache... Dydaktyka języków specjalistycznych. Lublin: Werset. Griffiths, C., red. 2008. Lessons from good language learners. Cambridge: Cambridge University Press. Grucza, F. 1994. „O językach specjalistycznych (= technolektach) jako pewnych składnikach rzeczywistych języków ludzkich”. W Języki specjalistyczne, red. F. Grucza, i Z. Kozłowska. Warszawa: Akapit, 7-27. Grucza, S. 2002. „Badania nad językami specjalistycznymi w Niemczech”. W Języki specjalistyczne, t. 2: Problemy technolingwistyki, red. J. Lewandowski. Warszawa: Katedra Języków Specjalistycznych UW, 81-100. Grucza, S. 2013. Lingwistyka języków specjalistycznych. Warszawa: Wydawnictwo Naukowe IKL@ UW. Hoffmann, L., Kalverkämper, H., i H. Wiegand. 1998. Fachsprachen. Ein internationales Handbuch zur Fachsprachenforschung und Terminologiewissenschaft. Berlin - New York: de Gruyter.

Hymes, D. 1964. Language in Culture and Society. New York: Harper and Row.

Jaroszewska, A. 2020. „Studium przypadku w badaniach glottodydaktycznych”. Neofilolog 54 (2): 245-268.

Jaworska, M. 2018. Nauczanie i uczenie się języków obcych młodzieży z dysleksją. Kraków: Oficyna Wydawnicza „Impuls”.

Kochan, M. 2010. „Mówiony język biznesu”. W Polskie języki. O językach zawodowych i środowiskowych, red. M. Milewska-Stawiany, i E. Rogowska-Cybulska. Gdańsk: Wydawnictwo UG, 139-175.

Ligara, B., i W. Szupelak. 2012. Lingwistyka i glottodydaktyka języków specjalistycznych na przykładzie języka biznesu. Podejście porównawcze. Kraków: Księgarnia Akademicka.

Łyda, A. 1997. „Wzorce leksykalne w języku biznesu”. W Języki specjalistyczne. Język biznesu, red. J. Arabski. Katowice: Wyższa Szkoła Zarządzania Marketingowego i Języków Obcych, 53-60.

Makowska, M. 2018. „Tekst multimodalny w glottodydaktyce”. Neofilolog 50 (2): 215-230.

Mamet, P. 2002. „Relacja pomiędzy kompetencją językową a kompetencją merytoryczną na przykładzie języka biznesu”. W Języki specjalistyczne, t. 2: Problemy technolingwistyki, red. J. Lewandowski. Warszawa: Katedra Języków Specjalistycznych UW, 141-151.

Matczak, A. 1992. „Z badań nad różnicami indywidualnymi w zakresie zdolności”. W Różnice indywidualne. Możliwości i preferencje, red. J. Strelau, W. Ciarkowska, i E. Nęcka. Wrocław - Warszawa - Kraków: Zakład Narodowy im. Ossolińskich - Wydawnictwo Polskiej Akademii Nauk, 83-98.

Mayer, R.E. 2013. „Uczenie się z wykorzystaniem technologii”. W Istota uczenia się. Wykorzystywanie wyników badań w praktyce, red. H. Dumont, D. Istance, i F. Benavides. Warszawa: OECD, 277-307. Neveling, Ch. 2004. „Wörterlernen mit Wörternetzen - eine kognitiv-affektive Strategie”. W Emotion und Kognition im Fremdsprachenunterricht, red. W. Börner, i K. Vogel. Tübingen: Narr, 190-216. 
Oxford, R. 1990. Language Learning Strategies: What Every Teacher Should Know. Boston: Heinle \& Heinle. Perrin, D. 2006. Medienlinguistik. Konstanz - München: UVK Verlagsgesellschaft.

Pomykało, W., red. 1995. Encyklopedia biznesu. T. 1. Warszawa: Fundacja „Innowacja”.

Raith, M. 2014. „Multimodales Verstehen und kulturelles Lernen. Zu einer Didaktik des Logovisuellen”.

W Visuelle Medien im DaF-Unterricht, red. M. Hieronimus. Göttingen: Universitätsverlag, 25-52.

Roelcke, T. 2001. Fachsprachen. Berlin: Erich Schmidt.

Schmäling, B. 2014. „Aktuelle Kurzfilme im DaF-Unterricht: «Feierlich reist» und «Fraktur»”. W Visuelle Medien im DaF-Unterricht, red. M. Hieronimus. Göttingen: Universitätsverlag, 319-334.

Schmitz, U. 2001. „Sehflächenforschung. Eine Einführung”. W Bildlinguistik: Theorien-Methoden - Fallbeispiele, red. H.J. Diekmannshenke. Berlin: Erich Schmidt Verlag, 23-42.

Siever, Ch.M. 2015. Multimodale Kommunikation im Social Web: Forschungsansätze und Analysen zu Text-Bild-Relationen. Frankfurt am Main: Peter Lang.

Spaniel-Weise, D. 2014. „Evaluationskriterien audio-visueller Verbundmedien für den DaF-/DaZ-Unterricht”. W Visuelle Medien im DaF-Unterricht, red. M. Hieronimus. Göttingen: Universitätsverlag, 53-76.

Spillner, B. 1983. „Methodische Aufgaben der Fachsprachenforschung und ihre Konsequenzen für den Fachsprachenunterricht”. W Fachsprache. Band 1. Sprachanalyse und Vermittlungsmethoden, red. H.P. Kelz. Bonn: Dümmler Verlag, 16-23.

Stöckl, H. 2004. Die Sprache im Bild - Das Bild in der Sprache. Zur Verknüpfung von Sprache und Bild im massenmedialen Text: Konzepte. Theorien. Analysemethoden. Berlin: de Gruyter.

Weidenmann, B. 2009. „Multimedia, Multicodierung und Multimodalität beim Online-Lernen”. W Online-Lernen, red. L. Issing, i P. Klimsa. Stuttgart: Oldenbourg Verlag, 73-86.

Wilczyńska, W., i A. Michońska-Stadnik. 2010. Metodologia badań w glottodydaktyce. Wprowadzenie. Kraków: Avalon.

Wilk-Janik, J. 2000. „Język biznesu: jego cechy i implikacje dla glottodydaktyki”. Neofilolog 19: 177-184. Wolff, D. 2004. „Kognition und Emotion im Fremdsprachenerwerb”. W Emotion und Kognition im Fremdsprachenunterricht, red. W. Börner, i K. Vogel. Tübingen: Narr, 87-103.

Żebrowska, E. 2013. Text-Bild - Hypertext. Frankfurt am Main: Peter Lang.

\title{
Language for Special Business Purposes from the Perspective of Foreign Language Learning and Teaching - Research Project
}

Keywords: language for special purposes, business language, language instruction for business purposes, specialised foreign language learning and teaching.

\begin{abstract}
The article is devoted to the teaching of languages for special business purposes from the perspective of foreign language learning and teaching. Growing needs related to the use of foreign languages in broadly understood business make this issue important both from the point of view of scientific discourse and in the context of search of new programme solutions. The specificity of communication activities, including not only the ability to communicate in a foreign language, but also specialist knowledge, knowledge of
\end{abstract}


terminology or cultural conditions of the communication process, as well as increasing didactic needs and expectations imply the need to conduct in-depth scientific analyzes in the field of language education for business needs. The paper presents a research project referring to selected aspects of language instruction at a higher education institution, with a particular emphasis on the teaching of German business language (as a foreign language). The importance of the problem and the state of the art knowledge on the matter as well as the assumptions behind the project, its goals, research problems and methodology are discussed. The main research question concerns the specific characteristics of the learning process and of the teaching of a business language at a higher education institution as well as the possibility of influencing it for optimisation purposes. The designed research is to enable a better understanding of the role of individual variables in the process of learning and teaching a specialized language for business needs, grasping the specificity of a learning strategy in this area and assess the possibilities of using new technologies and multimodal texts in education in the field of specialist language. 